\title{
Rooting Response of Air-Layered Shea (Vitellaria paradoxa) Trees to Media and Hormonal Application under Two Different Climatic Conditions
}

\author{
Julius Yeboah', Ben Kwaku Branoh Banful'2, Peter Yaw Boateng², Frank Manu Amoah', \\ Bonaventure Kissinger Maalekuu2 ${ }^{2}$, Samuel Tetteh Lowor1 \\ ${ }^{1}$ Cocoa Research Institute of Ghana, Tafo-Akim, Ghana \\ ${ }^{2}$ Department of Horticulture, Kwame Nkrumah University of Science and Technology, Kumasi, Ghana \\ Email: bproofa@gmail.com
}

Received 23 January 2014; revised 7 March 2014; accepted 21 March 2014

Copyright (C) 2014 by authors and Scientific Research Publishing Inc.

This work is licensed under the Creative Commons Attribution International License (CC BY).

http://creativecommons.org/licenses/by/4.0/

\section{Abstract}

Shea tree (Vitellaria paradoxa Gaertn. Family; Sapotaceae) indigenous to the Sudano-sahelian zone of Africa has great economic and ecological potential and attributes. Commercial cultivation of the tree is however, hampered by the poor rooting success of its planting material with adverse consequences on field establishment and total fruit yield. A $3 \times 2$ factorial experiment arranged in a randomized complete block design was carried out in 2012 at Bole in the Interior Savanna agro-ecological zone. The objective was to assess the rooting success of Shea shoots by the air-layering technique using two media types (palm fibre and Sphagnum moss) and three IBA hormone concentrations $(0,5000$ and $10,000 \mathrm{ppm})$ under contrasting climatic (wet and dry) conditions. Layered shoots which were sprayed with 10,000 ppm IBA and wrapped with Sphagnum moss gave significantly $(P<0.05)$ higher rooting success in terms of more roots per cutting $(73.3 \%)$ and longer roots per cutting $(9.0 \mathrm{~cm})$ than palm fibre at both $5000 \mathrm{ppm}(30.0 \% ; 3.7 \mathrm{~cm})$ and $10,000 \mathrm{ppm}(46.7 \% ; 7.9 \mathrm{~cm})$ concentrations. Higher rooting success was significantly achieved in the wet season than in the dry season. Sphagnum moss treated with $10,000 \mathrm{ppm}$ IBA facilitated the translocation of higher levels of sugar and total free phenol (TFP) to the base of the layered shoots which resulted in significantly $(P<0.05)$ higher number of roots and better roots protection from fungal infection than the other treatments. Rooting of layered shoots was affected to a greater extent by low temperatures (Rooting $=836-34.2$ Temp (low); $R^{2}=82 \%, p<0.001$ ) than by high temperatures (Rooting $=5250-175.0$ Temp (high); $R^{2}=64.5 \%, p<0.009$ ). Rooting of layered shoots was also significantly and negatively affected by the spread of the canopy of the selected tree such that closed canopy trees resulted in higher and better rooting that open canopy trees $\left(\right.$ Rooting = 113.87- 23.697 $\left(\right.$ Canopy spread); $\left.R^{2}=89 \%, p=0.002 ; n=9\right)$. Furthermore, significant 
and positive correlations were found between IBA concentration level and simple sugars ( $r=0.99$; $P<0.0001 ; n=9)$ and also between IBA concentration level and total free phenols $(r=0.98 ; P<$ $0.0002 ; n=9$ ). The study concluded that to achieve high rooting success in the propagation of Shea nut tree by the air-layering technique, a combination of Sphagnum moss treated with $10,000 \mathrm{ppm}$ of IBA hormone should be used and the whole set up carried out in the wet season.

\section{Keywords}

\section{Vitellaria paradoxa; Rooting; IBA Auxin; Palm Fibre; Sphagnum Peat Moss; Air-Layering}

\section{Introduction}

Shea (Vitellaria paradoxa Gaertn.) trees grow naturally throughout the Sudanian region from Senegal to the foothills of the Ethiopian highlands [1]. It is found in nineteen countries across East, Central and West Africa [2]. The tree is deciduous and characterized by a very slow growth habit [3]. In Ghana, Shea nut trees are mainly found in the Upper East, Upper West and Northern regions collectively designated as the interior savanna agro-ecological zone $\left(8-11^{\circ} \mathrm{N}\right)$. Small pockets of trees are also found in the Forest-Savanna transition areas of Brong Ahafo, Ashanti, Eastern and Volta regions. Economically, Shea nut contains shea butter which has characteristics similar to that of cocoa butter ([4] [5]). Consequently, shea butter easily substitutes for the highly demanded cocoa butter in the confectionery, pharmaceutical and cosmetic industries worldwide. In the designated regions of production, shea nut provides two very important sources of income in the realms of fruits picking by the youth and preparation and sale of shea butter by the women. In Mali, for instance, the shea butter tree provides more than $50 \%$ of the income of the village women [6].

In spite of these tremendous economic benefits, the Shea tree has a major drawback in its natural long gestation period which has been reported to be related to the poor rooting success of the trees during its establishment growth phase [7]. This phenomenon makes the Shea tree very unattractive for commercial cultivation. Several studies using cuttings have been undertaken in an attempt to overcome this undesirable trait with varying degrees of successes ([8]-[11]) which yet falls short of the level considered attractive for the commercial cultivation of the trees. Grafting [12] as a potential alternative technique is also less attractive because good root stocks need to be produced for about three years before the grafting could be effected thereby eliminating any potential reduction in the long undesirable gestation period. Opoku-Ameyaw (1996) [13] reported that with the relatively high rooting successes recorded using air-layering (top soil used as medium), this technique could be considered as the potentially viable one if other media considerations are investigated to further improve on the outputs of the technique. To this end, the objective of the study was to develop an air-layering technique using soilless medium in combination with high concentrations of IBA hormone for high level rooting of Shea tree seedlings.

\section{Materials and Methods}

\subsection{Characteristics of the Experimental Site}

The experiment was conducted at the Cocoa Research Institute of Ghana substation at Bole in the Northern region of Ghana, $9^{\circ} 01^{\prime} \mathrm{N}, 2^{\circ} 29^{\prime} \mathrm{W}$. The substation is located in the Interior Savanna agro-ecological zone which is characterized by high temperatures and low annual precipitation and humidity (Table 1).

\subsection{Experimental Procedure}

The experiment was carried out from May, 2012 to May, 2013 and laid out as a $2 \times 3$ factorial arranged in a randomized complete block design with three replications. The first factor was media type at two levels; sphagnum moss ( $3 \mathrm{~g}$ ) and palm fibre ( $3 \mathrm{~g}$ ). The second factor was indole-butyric acid (IBA) at three concentration levels; 0 ppm (water as control), $5000 \mathrm{ppm}$ and 10,000 ppm. There were a total of six treatments, replicated three times.

Shea trees in their reproductive stage of between 25 to 40 years were selected for the air-layering study. The bark of the semi-hardwood shoots were removed in a girdle width of between $2-3 \mathrm{~cm}$ and at a distance of be- 
Table 1. Climatic data from May 2012 to May, 2013.

\begin{tabular}{|c|c|c|c|c|c|}
\hline \multirow{2}{*}{ Month } & \multicolumn{2}{|c|}{ Mean Temperature ${ }^{\circ} \mathrm{C}$} & \multicolumn{2}{|c|}{ Mean Relative Humidity } & \multirow{2}{*}{$\begin{array}{c}\text { Total Rainfall } \\
\text { mm }\end{array}$} \\
\hline & Max & Min & $9.00 \mathrm{am}$ & $3.00 \mathrm{pm}$ & \\
\hline May 2012 & 30.0 & 24.5 & 82.0 & 70.0 & 115.8 \\
\hline June & 29.8 & 23.6 & 88.0 & 78.0 & 157.2 \\
\hline July & 29.8 & 23.2 & 84.0 & 71.0 & 121.7 \\
\hline August & 28.6 & 22.1 & 87.5 & 68.4 & 113.6 \\
\hline September & 30.3 & 24.5 & 90.6 & 79.0 & 215.4 \\
\hline October & 32.0 & 22.2 & 82.2 & 59.2 & 78.7 \\
\hline November & 33.8 & 21.6 & 73.4 & 50.7 & 15.9 \\
\hline December & 34.7 & 19.2 & 44.8 & 27.2 & 0.0 \\
\hline January 2013 & 35.1 & 20.1 & 30.4 & 20.1 & 0.0 \\
\hline February & 36.6 & 20.5 & 50.1 & 31.0 & 31.8 \\
\hline March & 35.3 & 23.3 & 73.1 & 45.1 & 111.0 \\
\hline April & 34.3 & 22.9 & 76.1 & 59.0 & 105.9 \\
\hline May 2013 & 33.3 & 22.8 & 76.5 & 60.6 & 117.3 \\
\hline
\end{tabular}

tween 15 - $18 \mathrm{~cm}$ [14] from the growing tip. There were 20 girdled stems per treatment. Each girdled portion was sprayed with the required IBA concentration, covered with the media type and tightly secured with a wrapping of white polythene sheet to ensure that the set up was air-tight. Occasionally, each set up was injected with $3 \mathrm{ml}$ of water to ensure the availability of moisture during the rooting process [14]. The experiment was carried out in both wet and dry seasons. Samples of the treated layered shoots were harvested for biochemical analysis to determine simple sugars and total free phenols.

Data were collected on 1) climatic parameters 2) canopy spread of selected trees 3) perimeter of selected trees 4) number of rooted layered shoots 5) number and length of developed roots 6) content of simple sugars and total free phenol (TFP) 7) moisture and mineral content of the media taken on same day of preparation.

\subsection{Statistical analysis}

Data were analyzed by analysis of variance (ANOVA), using Gentstat version 9. Counts data were square root transformed. Least significant differences (LSD) were calculated and the probability of treatment means being significantly different was set at $P=0.05$.

\section{Results}

\subsection{Nutrient Composition and Moisture Content of Media}

Sphagnum moss contained significantly higher levels of nitrogen $(\mathrm{N})$, organic carbon (OC), phosphorus $(\mathrm{P})$ and zinc (Zn) than the palm fibre (Table 2). The moss contained 13 times greater nitrogen, 2 times more organic carbon, and 1.3 times more zinc than the palm fibre. Phosphorus content was however 1.3 times greater in the palm fibre than in the moss. There were no significant differences in the calcium and potassium contents in the media. Both media also had similar alkaline reactions. In term of moisture content however, the Sphagnum moss contained 3.2 times more moisture than the palm fibre, the difference being significant (Table 2).

\subsection{Effect of Climatic Parameters on Rooting of Air-Layered Trees}

Atmospheric temperature, both high and low, significantly affected rooting of the air-layered trees. Low temperature levels affected rooting to a greater extent than high temperatures such that $82 \%$ (Equation (1)) of the variation in the rooting of the layered trees was affected by low temperatures as compared to $65 \%$ effect by high temperatures (Equation (2)).

$$
\begin{gathered}
\text { Rooting }=836-34.2 \text { Temp (low) } R^{2}=82 \%, p<0.001, \\
\text { Rooting }=5250-175.0 \text { Temp (high) } R^{2}=64.5 \%, p<0.009,
\end{gathered}
$$


Table 2. Nutrient and moisture contents of the media for the air-layering.

\begin{tabular}{|c|c|c|c|c|c|c|c|c|}
\hline \multirow{2}{*}{ Media } & \multicolumn{6}{|c|}{ Nutrient level (\%) } & \multirow{2}{*}{$\mathbf{p H}$} & \multirow[t]{2}{*}{ Moisture content (\%) } \\
\hline & Ca & $\mathbf{K}$ & $\mathbf{N}$ & OC & $\mathbf{P}$ & Zn & & \\
\hline Sphagnun moss & 0.5 & 1.0 & 1.3 & 38.9 & 4.2 & 4.9 & 8.5 & 9.4 \\
\hline Palm fibre & 0.5 & 0.9 & 0.1 & 18.3 & 5.6 & 3.0 & 8.4 & 2.9 \\
\hline $\operatorname{LSD}_{(0.05)}$ & 0.2 (ns) & 0.1 (ns) & 0.01 & 0.8 & 0.8 & 0.1 & 0.7 (ns) & 1.1 \\
\hline
\end{tabular}

Rooting of layered shoots was however not affected by the environmental relative humidity (high or low).

\subsection{Effect of Media Type and IBA Concentration on Rooting of Air-Layered Shoots in Wet and Dry Seasons}

There was significant $(\mathrm{P}<0.05)$ IBA concentration level and media type interaction for percentage rooting of layered shoots in the wet season. Layered shoots sprayed with 10,000 ppm in combination with Sphagnum moss covering produced $73.3 \%$ of rooted shoots, significantly greater than the other treatment combinations. The least percentage of rooted shoots was produced by either palm fibre (3.3\%) or Sphagnum (6.7\%) media covering in combination with water as control (Table 3).

In the dry season however, there were no significant differences in percentage of rooted shoots between the treatments. In general, rooting percentage in the dry season was extremely low, the highest being about $6.7 \%$.

There was a significant relationship between the canopy of the selected tree and the root production of the layered shoot expressed as $\mathrm{Y}=113.87-23.697 \mathrm{x}\left(\mathrm{R}^{2}=0.89 ; \mathrm{P}=0.002 ; \mathrm{n}=9\right)$. The spread of the canopy was negatively related to the roots developed on the layered shoots such that $89 \%$ of the variation in the rooting of the layered shoots was explained by the canopy spread of the selected tree. The relationship implied that the more dense the canopy, the better the rooting of the layered shoots.

There was also significant $(\mathrm{P}<0.05)$ IBA concentration level and media type interaction for root length of the layered shoots in the wet season. Layered shoots sprayed with 10,000 ppm in combination with Sphagnum moss covering produced 2.5 times longer roots than the mean of the shortest roots produced by either media covering in combination with water as control (Table 4).

In the dry season however, there were no significant differences in root length of layered shoots between the treatments.

A similar interaction trend was also observed for the number of developed roots such that layered shoots sprayed with 10,000 ppm IBA in combination with Sphagnum moss covering produced significantly $(\mathrm{P}<0.05)$ greater number of roots, three times more than the mean of the least number of roots produced by either media covering in combination with water as control (Table 5).

\subsection{Effect of Different Media on Fungal Infection of Roots in Layered Shoots}

Fungal infection of roots on layered shoots was significantly $(\mathrm{P}<0.05)$ lower under Sphagnum moss media than under palm fibre media. Root fungal infection was 5.5 times greater under palm fibre media than under Sphagnum moss media (Table 6).

\subsection{Relationships between IBA, Simple Sugars and Total Free Phenols}

There were highly significant and positive correlations between IBA and simple sugars as well as between IBA and total free phenols (Table 7).

\section{Discussion}

\subsection{Effect of Temperature on Rooting of Air-Layered Trees}

Ambient temperature had a significant effect on rooting of layered shoots. The extent of effect was however more pronounced by low temperatures compared to high temperatures. As a result rooting of shoots was more enhanced by the low temperatures during the study period than the high temperatures. Low to moderate temperatures has been reported to decrease bud elongation in advance of root initiation as well as decrease water loss from the leaves thus increasing the moisture status in the system for the layers to gain the potential benefit to 
Table 3. Effect of media and IBA concentration on rooting percentage of layered shoots in the wet season.

\begin{tabular}{cccc}
\hline & \multicolumn{3}{c}{ Rooted shoots (\%) Type of Media } \\
\hline IBA (ppm) & Palm fibre & Sphagnum moss & Mean \\
\hline Water (Control) & 3.3 & 6.7 & 5.0 \\
5,000 & 30.0 & 33.0 & 31.7 \\
10,000 & 46.7 & 73.3 & 60.0 \\
Mean & 26.7 & 37.8 & \\
\hline
\end{tabular}

LSD (5\%): Media = 9.7; IBA concentration = 11.9; IBA $\times$ Media = 16.8.

Table 4. Effect of media and IBA concentration on mean root length in the wet season.

\begin{tabular}{cccc}
\hline & \multicolumn{3}{c}{ Mean root length on shoots (cm) Type of Medium } \\
\hline IBA (ppm) & Palm fibre & Sphagnum moss & Mean \\
\hline Water (Control) & 2.8 & 4.5 & 3.7 \\
5000 & 3.7 & 4.8 & 4.4 \\
10,000 & 7.9 & 9.0 & 8.2 \\
Mean & 4.6 & 6.1 & \\
\hline
\end{tabular}

LSD (5\%): Media = 2.3; IBA concentration = 2.8; IBA $\times$ Media $=4.0$.

Table 5. Effect of media and IBA concentration on mean root length in the wet season.

\begin{tabular}{cccc}
\hline & & Number of developed roots on shoots Type of Media \\
\hline IBA (ppm) & Palm fibre & Sphagnum moss & 2.5 \\
\hline Water (Control) & 2.0 & 3.5 & 7.3 \\
5000 & 5.0 & 7.5 \\
10,000 & 6.0 & 4.5 \\
Mean & 4.3 & 6.8 \\
\hline
\end{tabular}

LSD (5\%): Media = 1.7(ns); IBA concentration = 2.0; IBA $\times$ Media = 2.9.

Table 6. Percent fungal infection on roots of layered shoots under different media.

\begin{tabular}{cc}
\hline Media & Infection (\%) \\
\hline Palm fibre & $36.7(43.9)$ \\
Sphagnum moss & $6.7(10.7)$ \\
LSD (5\%) & $23.9(22.6)$ \\
\hline
\end{tabular}

Figure in parenthesis are angular transformed value.

Table 7. Correlation between IBA and simple sugars and total free phenols.

\begin{tabular}{ccc}
\hline & Correlation coefficient $(\mathrm{r})$ & \\
\hline & Simple sugars & Total free phenols \\
IBA & 0.99 & 0.98 \\
& $\mathrm{P}<0.0001 ; \mathrm{n}=9$ & $\mathrm{P}<0.0002 ; \mathrm{n}=9$ \\
\hline
\end{tabular}

root [14]. Further, a temperature of $22^{\circ} \mathrm{C}-24^{\circ} \mathrm{C}$ has been found to be suitable for carbohydrate metabolism, cell division and root initiation [15]. Sivaci and Yalcin [16] also indicated that temperature was one of the factors that affected the seasonal changes of some important endogenous growth regulators in apples.

\subsection{Effect of IBA Concentration and Media Type on Rooting of Air-Layered Shoots in Wet and Dry Seasons}

Rooting of the layered shoots was better in number and in the length of the roots with the application of 10,000 ppm of IBA as compared to the 5000 ppm and control. Similar findings were made by Yeboah et al. ([7]-[11]) 
when higher concentrations of IBA (>5000 ppm) were also applied to shea tree cuttings. As an auxin, IBA most probably enhanced the translocation of carbohydrate and other endogenous plants substances and nutrients to the rooting zone for root initiation and development of the layered shoots. This implied that, the greater the concentration of IBA up to the threshold level, the better its efficiency of action. Additionally, the nutrient translocative ability of IBA might have resulted in more nutrients being translocated from the Sphagnum moss, with higher nutrients content than the palm fibre, for greater and better rooting of the layered shoots. Moreover the Sphagnum moss contained high levels of N, P, Zn and organic carbon, four very important nutrient elements which aid rooting. Nitrogen [17] and [18] were involved in protein synthesis and RNA production which signaled adventitious root development through cell organization. Additionally, Zinc played a role in auxin synthesis [14]. Phosphorus aided healthy root growth by enhancing the translocation of carbohydrates whereas organic carbon served as energy and raw material sources for microbial biomass [19].

The high and better rooting of the layered shoots covered with Sphagnum moss could also be attributed to the superior moisture retention ability of the Sphagnum moss compared to the palm fibre. Hutcheon et al. [20] observed that the presence of moisture in a media reduced plant stress and enhanced biochemical and physiological functions leading to enhanced metabolic activities during the rooting process. Further, the high moisture content of the media provided a regime for efficient functioning of microorganisms that were involved in organic matter decomposition and nutrient release.

In terms of the climatic conditions, rooting was better in the wet season than the dry season which could be due to the low temperatures experienced during the wet season which has a significant and positive effect on rooting of the layered shoots. In the study area, the dry season is characterized by very extreme temperatures which could partly explain the observed low rooting of the layered shoots. Hartmann et al. [14] indicated that extremely high temperatures, $>32^{\circ} \mathrm{C}$, hasten evapo-transpiration rate, slow down cell processes, cause injury to cells, and eventually impede rooting.

\subsection{Effect of Synthesized Biochemical Products on Rooting and Root Protection}

Layered shoots treated with 10,000 ppm IBA and covered with Sphagnum moss synthesized higher levels of sugar $(785.5 \mathrm{mg} / \mathrm{g})$ and phenols (19.0 mg/g). Biochemical studies on the rooting of Shea tree ([9] [21] [22]) and other crops ([23] [24]) clearly indicated that sugars and phenols played a role in root formation. IBA bound sugar molecules and translocated them to the base of the shoot to provide energy for the rooting process ([25] [23]). For the phenols, the IBA bound the phenol molecules and translocated them to the base of the shoot to prevent infection of the developed roots as well as serve as protection against the oxidation of the IBA by IAA-oxidase ([14] [26]).

Root fungal infection enhanced by the palm fibre media possibly affected the rooting success by interfering with the movement of some important plant substances responsible for cell functions ([14] [27] [28]).

\section{Conclusion}

The study clearly demonstrated that to achieve high rooting success in the propagation of Shea tree, the airlayering technique using Sphagnum moss treated with 10,000 ppm IBA hormone was the best. The study also showed that low temperature was critical to the success of the rooting and as such the technique should always be practiced only in the wet season when low temperatures are assured. Further, the availability of plant substances like sugars and total free phenols were also of importance in the rooting success of the layered shoots. Finally, selecting a compact canopy tree was better than an open canopy tree since the former produced better rooting successes of the layered shoots of the Shea tree.

\section{Acknowledgements}

The authors express sincere thanks to the Technical Staff at the CRIG substation at Bole and the Physiology and Biochemical Division at CRIG Head Office in Tafo, for the data collection and chemical analysis, respectively.

This publication No. CRIG/012/2014/017/001 is published by the kind permission of the Executive Director of the Cocoa Research Institute of Ghana.

\section{References}

[1] White, F. (1983) The Vegetation of Africa. UNECSO, Natural Resources Research, 20. 
[2] FAO (1988) Traditional Food Plants. Food and Nutrition Paper, FAO, Rome, 125-129.

[3] Dalziel, J.M. (1955) The useful plants of Tropical Africa. 3rd Edition, Crown Agents, London.

[4] Adomako, D. (1974) Comparative Study of Cocoa, Sheanut and Tallow (Pentedesma butyracea sp.) Fats. Annual Report, Cocoa Research Institute of Ghana, 178-179.

[5] Adomako, D. (1975) Cocoa Butter, Shea Butter and Tallow Fat. Annual Report, Cocoa Research Institute of Ghana, 65.

[6] Spore (1991) The Shea Butter Tree’s Untapped Riches. Spore, Crop Production and Protection, No. 32, 5.

[7] Yeboah, J., Lowor, S.T., Boateng, P.Y. and Amoah, F.M. (2010) Some Physiological and Environmental Factors that affect the Vegetative Propagation of the Shea (Vitellaria paradoxa C.F. Gaertn) Tree. International Journal of Tropical Agriculture and Food Systems, 3, 170-177.

[8] Yeboah, J., Lowor, S.T. and Amoah, F.M. (2009) The Rooting Performance of Shea (Vitellaria paradoxa C. F. Gaertn) Cuttings Leached in Water and Application of Rooting Hormone in Different Media. Journal of Plant Sciences, 4, 1014. http://dx.doi.org/10.3923/jps.2009.10.14

[9] Yeboah, J., Lowor, S.T. and Amoah, F.M. (2009) The Rooting Performance of Shea (Vitellaria paradoxa C. F. Gaertn) Cuttings as Influence by Woodtype Sucrose and Rooting Hormone. Scientific Research and Essay, 4, 521-525.

[10] Yeboah, J., Lowor, S.T., Amoah, F.M. and Owusu-Ansah, F. (2010) Propagation Structures and Some Factors That Affect the Rooting Performance of Sheanut (Vitellaria paradoxa C. F. Gaertn) Cuttings. Agiculture and Biology Journal of North America, 2, 258-269.

[11] Yeboah, J., Akrofi, A.Y. and Owusu-Ansah, F. (2010) Influence of Selected Fungicides and Hormone on the Rooting Success of Shea (Vitellaria paradoxa C. F. Gaertn) Stem Cuttings. Agiculture and Biology Journal of North America, 1, 313-320. http://dx.doi.org/10.5251/abjna.2010.1.3.313.320

[12] Sanou, H., Kambou, S., Teklehaimanot, Z., Dembélé, M., Yossi, H. Sina, S., Djingdia, L. and Bouvet, J.-M. (2004) Vegetative Propagation of Vitellaria paradoxa by Grafting. Agroforestry Systems, 60, 93-99. http://dx.doi.org/10.1023/B:AGFO.0000009408.03728.46

[13] Opoku-Ameyaw, K. (1996) Sheanut Experiments. Report, Cocoa Research Institute of Ghana, Bole Substation, 225228.

[14] Hartmann, H.T., Kester, D.E., Davies, F.T. and Geneve, R.L. (2002) Plant Propagation, Principles and Practices. 7th Edition. Prentice Hall Engineering, Cliff, 275-551.

[15] Moore, K.G., Illsley, A. and Lovell, P.H. (1975) The Effects of Temperature on Root Initiation in Detached Cotyledons of Sinapis alba L. Annals of Botany, 39, 657-669.

[16] Sivaci, A. and Yalcin, I. (2008) The Seasonal Changes in Endogenous Levels of Indole-3-Acetic Acid, Gibberellic acid, Zeatin and Abscisic Acid Stems of Some Apple Varieties (Malus sylvestris Miller). Asian Journal of Plant Sciences, 7, 319-322.

[17] Jain, M.K. and Nanda, K.K. (1972) Effect of Temperature and Some Antimetabolites on the Interaction Effects of Auxin Nutrition in Rooting Etiolated Stem Segments of Salix tetrasperma. Physiologia Plantarum, 27, 169-172. http://dx.doi.org/10.1111/j.1399-3054.1972.tb03595.x

[18] Cakmak, I. (2000) Possible Roles of Zinc in Protecting Plant Cells from Damage by Reactive Oxygen Species. New Phytologist, 146, 185-205. http://dx.doi.org/10.1046/j.1469-8137.2000.00630.x

[19] Noggle, G.R. and Fritz, J.F. (1983) Introductory Plant Physiology. 2nd Edition, Prentice Hall Inc., Englewood Cliffs, 440-442.

[20] Hutcheon, V.W., Smith, R.W. and Asomaning, E.J.A. (1973) Effect of Irrigation on the Yield and Physiological Behaviour of Matured Amelonado cocoa in Ghana. Tropical Agriculture, 50, 261-272.

[21] Akakpo, B., Amissah, N., Yeboah, J. and Blay, E. (2013) Effect of Indole-3-Butyric Acid and Media Type on Adventitious Root Formation in Sheanut Tree (Vitellaria paradoxa C. F. Gaertn) Stem Cuttings. American Journal of Plant Sciences, 5, 313-318. http://dx.doi.org/4236/ajps.2014.53043

[22] Amissah, N., Akakpo, B., Yeboah, J. and Blay, E. (2013) Asexual Propagation of the Shea (Vitellaria paradoxa C. F. Gaertn) Tree Using a Container Layering Technique. American Journal of Plant Sciences, 4, 1758-1764. http://dx.doi.org/10.4236/ajps.2013.49216

[23] Das, P., Basak, U.C. and Das, A.B. (1997) Metabolic Changes during Rooting in Pre-Girdled Stem Cuttings and Air-Layers of Heritiera. Botanical Bulletin of Academia Sinica, 38, 91-95.

[24] Gabryszewska, E. (2011) Effect of Various Levels of Sucrose, Nitrogen Salts and Temperature on the Growth and Development of Syringa vulgaris L. Shoots in Vitro. Journal of Fruit and Ornamental Plant Research, 19, $133-148$.

[25] Woodward, A.W. and Bartel, B. (2005) Auxin: Regulation, Action and Interaction. Annals of Botany, 95, 707-735. 
http://dx.doi.org/10.1093/aob/mci083

[26] Pandey, D. and Pathak, R.K. (1981) Effect of Rootstocks, IBA and Phenolic Compounds on the Rooting of Apple Cuttings. Propagation of Horticulture, 13, 105-110.

[27] James, B.L. (1993) Update on fungicides. Combined Proceedings of International Plant Propagators’ Society, 43, 373-375.

[28] Amstrong, M. (1992) Integreted Disease Management-Research and Development Using New Techniques and Bioremediation of Vans Pines. Combined Proceedings of International Plant Propagators' Society, 42, 502-506. 